\title{
Gregariousness in the gorgonian-eating gastropod Cyphoma gibbosum: tests of several possible causes
}

\author{
Donald J. Gerhart* \\ Department of Ecology and Evolution, SUNY at Stony Brook, Stony Brook, New York 11794, USA
}

\begin{abstract}
The ovulid gastropod Cyphoma gibbosum is a widespread and common predator of gorgonian octocorals ('sea whips') on Caribbean coral reefs. C. gibbosum is not randomly distributed, but tends to be clumped into small groups. To examine possible causes of this phenomenon, field and laboratory experiments were performed with C. gibbosum and Plexaura homomalla, a common Caribbean gorgonian. These experiments suggest that clumping in $C$. gibbosum is produced by mucous trail following. Gregariousness may have evolved in $C$ gibbosum to increase the protection afforded by distastefulness and aposematism, although other explanations cannot be excluded. Octocoral-gastropod interactions possess several important parallels to terrestrial plant-herbivore systems. Further comparison of these systems may provide new insights into predator-prey coevolution.
\end{abstract}

\section{INTRODUCTION}

Gorgonians (Coelenterata: Anthozoa: Octocorallia) are common, conspicuous members of Caribbean coral reef communities. In spite of their conspicuousness, gorgonians are rarely eaten by predators (Randall 1967, Vermeij 1978, Bakus 1981). This observation is intriguing, since predation on coral reefs is intense (Glynn et al. 1972, Bakus 1964, 1971, 1981, Sammarco et al. 1974, Brock 1979, Sammarco 1980, Huston 1985).

Gorgonians possess several lines of defense against predators, including sclerites of calcium carbonate (Bayer 1961), nematocysts (Barnes 1980, Hyman 1940), and large amounts of secondary compounds (Tursch et al. 1978, Fenical 1982, Faulkner 1984). Since predation can play an important role in the structuring of ecological communities (Slobodkin 1962, Paine 1966), these defenses may significantly affect the patterns of distribution and abundance of gorgonians.

A few organisms have circumvented the defenses of gorgonians. Perhaps the most notable of these is Cyphoma gibbosum, a gastropod in the family Ovulidae. This snail, which is common on coral reefs

- Present address: Department of Chemistry, 2545 The Mall, University of Hawaii at Manoa, Honolulu, Hawaij 96822, USA

(C) Inter-Research/Printed in F. R. Germany throughout the Caribbean (Ghiselin \& Wilson 1966, Kinzie 1971), feeds exclusively on gorgonians.

Kinzie (1971) concluded that Cyphoma gibbosum was a generalist within the order Gorgonacea, with no inter-specific prey preferences. Other studies suggest that Cyphoma gibbosum favors certain species of gorgonians (Birkeland \& Gregory 1975). For any given prey species, however, individual Cyphoma gibbosum are not distributed randomly, but tend to be clumped into small groups (Birkeland \& Gregory 1975, Hazlett \& Bach 1982). The most dramatic examples of clumping are those reported by Kinzie (1971) of a group of $17 C$. gibbosum grazing on a single gorgonian colony, and the observations of Birkeland \& Gregory (1975) of aggregations of 16,28 , and 35 individuals.

Hazlett \& Bach (1982) found that the clumped distribution of Cyphoma gibbosum was not explained by colony size, or by the distance to the nearest neighboring gorgonian colony. These authors contended that clumping could be produced by intercolony variation in the quality of the gorgonians, as perceived by the snails. Hazlett \& Bach suggested that these differences in prey quality could be the result of intraspecific variation in the secondary metabolite content of gorgonians.

Variation in secondary metabolite content is well 
documented in Plexaura homomalla, an abundant gorgonian on shallow Caribbean coral reefs. A single chemical compound, prostagiandin $\mathrm{A}_{2}\left(\mathrm{PGA}_{2}\right)$, comprises 2 to $8 \%$ of the wet weight of $P$. homomalla (Weinheimer \& Spraggins 1969, Schneider et al. 1977 , Dominguez et al. 1980). Prostaglandins are fatty-acid derivatives with potent, hormone-like effects on a wide range of biological processes (Hall \& Behrman 1982). $\mathrm{PGA}_{2}$ appears to provide $P$. homomalla with an effective defense against predatory fish (Gerhart 1984a, b). In spite of the large amount of $\mathrm{PGA}_{2}$ in its tissues, however, $P$. homomalla is readily consumed by Cyphoma gibbosum (Kinzie 1971, Gerhart 1984b).

The prostaglandin content of Plexaura homomalla varies from location to location within the Caribbean (Schneider \& Morge 1971, Schneider et al. 1977 , Gerhart 1984b). In some areas, colonies contain 15(S)$\mathrm{PGA}_{2}$, while in other locations, $P$. homomalla contains mostly the $15(\mathrm{R})$ isomer of $\mathrm{PGA}_{2}$. In several mammalian bioassays, $15(\mathrm{~S})-\mathrm{PGA}_{2}$ is highly potent, while

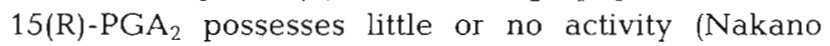
1968, 1969, Nakano \& Kessinger 1970, Spraggins 1972). If the activity differences of 15(R)- and 15(S)$\mathrm{PGA}_{2}$ in Cyphoma gibbosum parallel those observed in mammals, then C. gibbosum may prefer colonies of Plexaura homomalla which contain the less potent 15(R) isomer of $\mathrm{PGA}_{2}$.

Thus, the clumped distribution of Cyphoma gibbosum may occur because some prey colonies are more acceptable to the snails than others. If so, then snails transplanted to gorgonian colonies that were previously occupied by $C$. gibbosum should remain longer, on average, than snails moved to previously vacant colonies. Furthermore, if differences in the acceptability of colonies are caused by variation in secondary metabolite content, this variation should be demonstrable by chemical analysis of the tissue.

Alternatively, snails may choose colonies at random, and subsequently attract other snails to the occupied colony. If this is true, then Cyphoma gibbosum transplanted to previously vacant colonies should remain as long, on average, as those moved to previously occupied colonies. Furthermore, consistent chemical differences between occupied and vacant colonies should not be found, and snail-occupied gorgonians should be chosen more frequently than unoccupied gorgonian colonies.

The latter hypothesis presumes that snails have, for some unknown reason, evolved gregarious behavior. In terrestrial insects, gregariousness is frequently associated with distastefulness, presumably to better exploit the defensive benefits of unpalatability (Fisher 1958). Cyphoma gibbosum appears to sequester secondary chemicals from its gorgonian prey (Steudler et al. 1977). Since many gorgonian secondary compounds are toxic or noxious (Tursch et al. 1978, Bakus 1981), C. gibbosum also may be distasteful. If so, then gregariousness in this snail may lead to decreased susceptibility to predation.

To test these hypotheses, I performed a series of field and laboratory experiments at Curaçao, Netherlands Antilles, where Plexaura homomalla reportedly contained a mixture of $15(\mathrm{R})$ - and $15(\mathrm{~S})$ - $\mathrm{PGA}_{2}$ (Schneider \& Morge 1971). The objectives of these experiments were: (1) to document the distribution of Cyphoma gibbosum on colonies of Plexaura homomalla; (2) to determine if snail-grazed colonies of $P$. homomalla differed significantly from ungrazed colonies in their size, population density, proximity to other gorgonians, or prostaglandin isomer content; (3) to determine if colonies of $P$. homomalla that were previously chosen by $C$. gibbosum were more acceptable to the snails than colonies that had not been chosen; (4) to determine whether individuals of $C$. gibbosum attracted others as they grazed on their gorgonian prey; (5) to elucidate the role of mucous trail following in the production of the clumped distribution of $C$. gibbosum; (6) to determine whether $C$. gibbosum was unpalatable to predators.

\section{MATERIALS AND METHODS}

The study was performed at Kaap Malmeeuw and at CARMABI Buoy Two on the southwest coast of Curaçao. These locations have been described by Van den Hoek et al. (1978).

Intercolony distribution of Cyphoma gibbosum. Fifty colonies of Plexaura homomalla were selected haphazardly and marked with numbered plastic tags. Tags were tied to a nearby piece of dead coral to reduce disturbance of the gorgonian. The colonies were examined 4 to 5 times $\mathrm{wk}^{-1}$, from September 13 through November 7, 1983. Five additional colonies of $P$. homomalla, each occupied by at least 2 snails, were added to the study on September 27, 1983. All observations were made using SCUBA.

The following data were taken for each numbered colony: (1) the distance to the nearest neighboring gorgonian; (2) the distance to the nearest neighboring colony of Plexaura homomalla; (3) the distance to nearest gorgonian colony occupied by a snail; (4) the maximum height of the colony. Tissue samples were collected from each colony at the end of the study and later analyzed by high efficiency thin-layer chromatography (HETLC) to determine the 15(R)- and 15(S) $-\mathrm{PGA}_{2}$ content of the tissue (Schneider \& Morge 1971, Schneider et al. 1977, Gerhart 1984b).

Transplant experiments with Cyphoma gibbosum. During the months of October and November 1984, 54 
colonies of Plexaura homomalla were tagged at CARMABI Buoy Two. Of these colonies, 22 were occupied by Cyphoma gibbosum, and the remainder were vacant. At the beginning of the experiment, all snails were removed from the occupied colonies. Single snails were placed on some colonies to produce 5 treatments. In Treatment A, 12 previously occupied colonies were kept without snails. In Treatment B, a single snail was added to each of 11 colonies, all previously occupied. In Treatment C, 1 snail was transplanted to each of 11 previously vacant colonies. Treatment D was comprised of 11 colonies, all previously vacant, which were artificially damaged on each day of observation by removing 1 to $2 \mathrm{~cm}^{2}$ of tissue with a knife. Treatment $E$, in which 10 previously vacant colonies were left undisturbed, served as a control. The unique mantle markings of each snail were observed and recorded so that individual snails could be recognized.

On each day of observation, the number of snails on a colony was noted. Colonies in Treatments $B$ and $C$ were maintained at 1 snail per colony, by adding a new snail to vacated colonies, and by removing colonizing snails if more than 1 snail was present. All colonies were observed 7 times. Observations were terminated after $9 \mathrm{~d}$ due to a severe, week-long storm which subjected the study site to heavy wave surge and siltation

Mucous trail following. The following experiment was performed to determine whether mucous trails influenced the prey choices of Cyphoma gibbosum.

Individuals of Cyphoma gibbosum were collected from Plexaura flexuosa or P. homomalla and placed in a seawater table. A section of the original host colony was also collected and transferred to the seawater table. Two branches of equal size were cut from the section of gorgonian, and mounted in holders on a plexiglas plate. A snail was then placed on the plexiglas at a point equidistant from the 2 gorgonian. branches, and allowed to choose one of the branches. If the snail moved off the plexiglas without choosing either branch, its mucous trail was removed by grasping it, peeling it off the plexiglas, and then rubbing off any adhering strands of mucous. The snail was then replaced at the origin and permitted to choose again. This process was repeated until the snail chose one gorgonian branch or the other. This constituted one run of the experiment. After the first run, a mucous trail led from the starting point to one of the 2 gorgonian branches. In subsequent runs, snails were placed at the same starting point. After 5 runs, all mucous was removed from the plexiglas, and the experiment was repeated.

Three controls were employed. To ensure that the choices of the snails were not biased by their surroundings, the plexiglas plate was rotated 90 degrees after the second run and after each subsequent run. To make sure that the snails were not influenced by differences in the gorgonian branches, the branches were switched between Runs 3 and 4 . Finally, to ensure that choices were not biased by some inherent tendency of the snail to move left or right, 5 snails were allowed to choose several times, but their mucous trails were removed from the plexiglas after each run. The directions of the turns of each snail were recorded.

Assay of the palatability of snail tissues. Four Cyphoma gibbosum were killed by chilling, and then dissected into sections of mantle, viscera, and foot muscle. Foot muscle was carefully skinned to remove adhering mantle and mucous glands. Sections of these tissues were then offered one at a time, underwater, to bluehead wrasses Thalassoma bifasciatum. The acceptance or rejection of each piece of tissue was recorded. Pieces of fish, cut to the same size as the sections of snail tissues, were offered as a control. To determine whether the wrasses became satiated during the course of the experiment, the pieces of fish were offered at the beginning and end of the experiment.

Statistical methods. All statistical tests were performed using the procedures described in Sokal \& Rohlf (1981).

\section{RESULTS}

\section{Intercolony distribution of Cyphoma gibbosum}

The distribution of Cyphoma gibbosum on the 50 randomly selected colonies of Plexaura homomalla is given in Table 1 . This distribution differs significantly from random expectation ( $G$ test for goodness-of-fit to a Poisson distribution; $G=6.4 ; \quad P<0.025)$. Multiple groups were observed more frequently than expected on the basis of chance, while single snails were observed less frequently.

The average number of snails per day observed on a

Table 1. Cyphoma gibbosum. Summary of distribution on 50 randomly selected colonies of Plexaura homomalla. Data are from the 1 st day of observation in 1983. Observed frequencies differ significantly from random expectation $(0.025>\mathrm{P}$ $>0.01$ )

$\left.\left.\begin{array}{|ccc|}\begin{array}{c}\text { Number of } \\ \text { snails per } \\ \text { colony }\end{array} & \begin{array}{c}\text { Observed } \\ \text { frequency }\end{array} & \begin{array}{c}\text { Poisson } \\ \text { expected } \\ \text { frequency }\end{array} \\ \hline 0 & 41 & 37.8 \\ 1 & 5 & 10.8 \\ 2 & 3 \\ 3 & 1\end{array}\right\} 4 \quad \begin{array}{c}1.5 \\ 0.1\end{array}\right\} 1.6$


colony during the study period was not significantly correlated with the size of the colony $\left(\mathrm{r}_{\mathrm{s}}=0.208, \mathrm{P}>\right.$ $0.05)$, nor was it significantly correlated with distance to the nearest neighboring gorgonian colony $\left(\mathrm{r}_{\mathrm{s}}=\right.$ $-0.122, P>0.2)$, distance to the nearest colony of Plexaura homomalla $\left(\mathrm{r}_{\mathrm{s}}=-0.016, \mathrm{P}>0.2\right)$, or distance to the nearest colony occupied by a snail $\left(\mathrm{r}_{\mathrm{s}}=-0.188\right.$, $\mathrm{P}>0.1$ ).

All 55 colonies of Plexaura homomalla examined in 1983 contained only 15 (S)-PGA $A_{2}$. Thus, snail-occupied colonies of $P$. homomalla did not differ in their $\mathrm{PGA}_{2}$ isomer content from colonies which were unoccupied. Furthermore, no other qualitative differences in the chemical content of occupied colonies could be detected by the HETLC analyses (Fig. 1). This result was confirmed by additional sampling and analysis of 13 snail-occupied and 45 unoccupied colonies in 1984.

An earlier report (Gerhart 1984b) erroneously stated

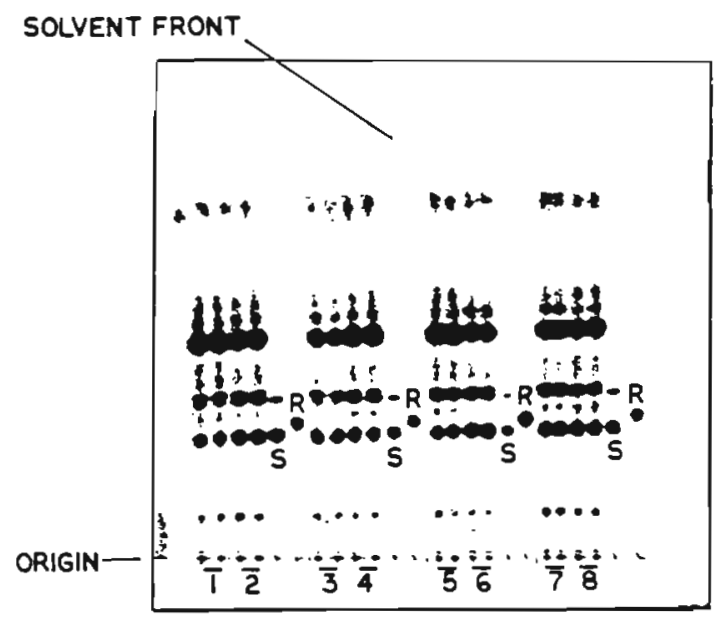

Fig. 1. One plate from the HETLC analysis of gorgonian tissue. The sample in lane 2 is from a snail-occupied colony. Samples in other lanes are from vacant colonies. ' $\mathrm{S}$ ' is written below standards of $15(\mathrm{~S})-\mathrm{PGA}_{2}$, while ' $\mathrm{R}$ ' is written above standards of $15(\mathrm{R})-\mathrm{PGA}_{2}$ that Plexaura homomalla from Curaçao contained $15(\mathrm{~S})-\mathrm{PGA}_{2}$ mixed with varying amounts of $15(\mathrm{R})$ $\mathrm{PGA}_{2}$, and that the amount of $15(\mathrm{R})-\mathrm{PGA}_{2}$ seemed to vary clinally with depth and wave exposure. This is not the case. What had appeared to be $15(\mathrm{R})-\mathrm{PGA}_{2}$ in earlier work was actually a different compound with TLC mobility closely approximating that of $15(\mathrm{R})$ $\mathrm{PGA}_{2}$. Using slightly modified TLC conditions, this compound was consistently more mobile than 15(R)$\mathrm{PGA}_{2}$, and gave a different color when visualized with $10 \%$ phosphomolybdic acid in ethanol, followed by heating. The compound was present in all freshly collected samples of $P$. homomalla.

\section{Transplant experiments with Cyphoma gibbosum}

The movements of Cyphoma gibbosum to and from colonies of Plexaura homomalla are summarized in Table 2. The number of colonizations by $C$. gibbosum of previously vacant colonies (Treatments C, D, and E) was low; these frequencies of colonization did not differ significantly from each other ( $G$ test for independence, $P>0.1$ ). The number of colonizations for previously occupied colonies with no added snails (Treatment A) was somewhat higher, but did not differ significantly from the expected rate of colonization, which was calculated by combining the data for previously vacant colonies (G test for goodness-of-fit, $\mathrm{P}>0.1$ ). Previously occupied colonies with 1 added snail (Treatment $B$ ) showed a significantly higher rate of colonization than expected ( $G$ test, $G=9.8$, $\mathrm{P}<0.005$ ).

Some gorgonian colonies were repeatedly selected by Cyphoma gibbosum. In Treatment A (previously occupied colonies, no snails added), all 4 colonizing snails chose the same colony. In Treatment B (previously occupied colonies, 1 snail added), the 8 colonizing snails were distributed over 3 colonies.

Table 2. Data and description of treatments in the snail transplant experiment

\begin{tabular}{|c|c|c|c|c|}
\hline Treatment & $\begin{array}{l}\text { Number of } \\
\text { Colonies }\end{array}$ & $\begin{array}{l}\text { Number of } \\
\text { colonized } \\
\text { gorgonians }\end{array}$ & $\begin{array}{l}\text { Number of } \\
\text { colonizing } \\
\text { snails }\end{array}$ & $\begin{array}{l}\text { Number of } \\
\text { snails leaving } \\
\text { the colony }\end{array}$ \\
\hline $\begin{aligned} \text { A: } & \text { Previously occupied } \\
& \text { colony, no snails added }\end{aligned}$ & 12 & 1 & 4 & - \\
\hline $\begin{array}{l}\text { B: Previously occupied } \\
\text { colony, } 1 \text { snail added }\end{array}$ & 11 & 3 & 8 & 21 \\
\hline $\begin{aligned} \text { C: } & \text { Previously vacant } \\
& \text { colony, } 1 \text { snail added }\end{aligned}$ & 11 & 0 & 0 & 8 \\
\hline $\begin{aligned} D: & \text { Previously vacant } \\
& \text { colony, artificially damaged }\end{aligned}$ & 11 & 2 & 2 & - \\
\hline $\begin{array}{l}\text { E: Previously vacant } \\
\text { colony, no snails added }\end{array}$ & 10 & 2 & 2 & - \\
\hline
\end{tabular}


Sixty \% (9 of 15) of the colonizations occurred less than $48 \mathrm{~h}$ after a previous colonization or desertion. This frequency was higher than expected by chance ( $G$ test for goodness-of-fit; $\mathrm{G}=5.2 ; \mathrm{P}<0.025)$.

Transplanted Cyphoma gibbosum remained longer on previously vacant colonies than on previously occupied colonies (Fig. 2; Wilcoxon 2 Sample Test; $\mathrm{P}<0.01$ ).
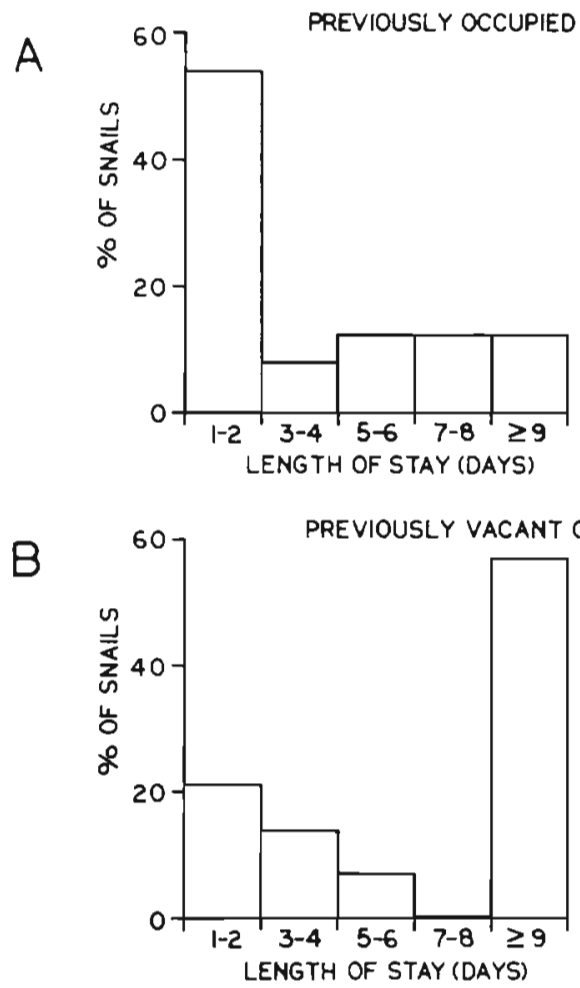

Fig. 2. Cyphoma gibbosum. Lengths of stay when transplanted to (A) previously occupied colonies of Plexaura homomalla, $(B)$ previously vacant colonies of $P$. homomalla

\section{Mucous trail following}

Fourteen snails were offered a choice between a gorgonian branch with a mucous trail leading to it, and another branch without a mucous trail. Twelve snails chose the branch with a trail leading to it, while 2 chose the other branch. This result was significantly different from random expectation, assuming an equal chance of choosing either branch ( $G$ test for goodnessof-fit, $G=7.6, P<0.01$ ).

When the mucous trails were removed between runs, Cyphoma gibbosum made 12 turns to the right and 13 turns to the left.

\section{Assay of distasteful qualities of snail tissues}

The acceptance and rejection of sections of snail tissue are shown in Table 3. Mantle tissue was rejected significantly more frequently than the control food items ( $G$ test, $G=19.1, P<0.005$ ). All pieces of fish were eaten, whether offered at the beginning or the end of the experiment.

\section{DISCUSSION}

The distribution of Cyphoma gibbosum on colonies of Plexaura homomalla is not random. Rather, snails tend to congregate on certain colonies. This result confirms earlier observations that $C$. gibbosum is gregarious (Birkeland \& Gregory 1975, Hazlett \& Bach 1982).

Cyphoma gibbosum does not favor previously occupied colonies over previously vacant colonies. Rather, the opposite appears to be true: C. gibbosum placed on previously occupied colonies left more quickly than snails transplanted to previously vacant colonies (Fig. 2A, B). Thus, grazing seems to decrease the acceptability of colonies of Plexaura homomalla to C. gibbosum. This decreased acceptability could be due to the mobilization of predation-induced defenses in the gorgonian, or to a decrease in the nutritive quality of the tissue due to grazing. The decrease in acceptability also may result simply from the removal of tissue from the colony, thus reducing the total amount of tissue available to each occupying snail. Although HETLC indicated no qualitative differences in grazed versus ungrazed colonies of $P$. homomalla, increases in the amount of secondary compounds can-

Table 3. Acceptance and rejection of tissues of Cyphoma gibbosum by the bluehead wrasse Thalassoma bifasciatum. Sections of fish were offered as a control

\begin{tabular}{|lccc|}
\hline $\begin{array}{l}\text { Type of } \\
\text { tissue }\end{array}$ & $\begin{array}{c}\text { Number of pellets } \\
\text { eaten immediately }\end{array}$ & $\begin{array}{c}\text { Number of pellets } \\
\text { rejected, then eaten }\end{array}$ & $\begin{array}{c}\text { Number of pellets } \\
\text { inspected and ignored }\end{array}$ \\
\hline Fish & $15(100 \%)$ & 0 & 0 \\
Foot & $6(100 \%)$ & 0 & 0 \\
Viscera & $3(75 \%)$ & $1(25 \%)$ & 0 \\
Mantle & $4(31 \%)$ & $6(46 \%)$ & $3(23 \%)$ \\
\hline
\end{tabular}


not be ruled out, since quantitative chemical differences between colonies could not be reliably detected by HETLC.

Cyphoma gibbosum appears systematically to sample newly encountered gorgonians. Snails sometimes make trails of regularly spaced, shallow bites on the gorgonians which they occupy (Fig. 3). Of the trails observed on 50 colonies in the field during $11 \mathrm{~d}$ of observation in 1983, over $80 \%$ (13 of 16) were produced by newly colonizing snails (Gerhart 1984b). The remainder were made by snails which moved to a new part of the gorgonian. Sampling trails were also observed on other species of gorgonians in the same area. This behavior suggests that snails routinely and methodically sample newly-encountered gorgonian tissue, perhaps to assay its quality.

Individuals of Cyphoma gibbosum do not attract others as they graze upon their prey. In the snail transplant experiment, artificial damage (Treatment D) did not seem to attract snails, nor did snails appear to attract others by releasing a diffusible substance, since previously vacant colonies with added snails (Treatment C) were not colonized during the study period.

Cyphoma gibbosum produced mucous trails in the field and in the laboratory. In the laboratory, these mucous trails strongly influenced the prey choices of C. gibbosum. Mucous trails also seemed to influence prey choices in the field; $C$. gibbosum frequently colonized gorgonians which were recently vacated or occupied, suggesting that the snails could detect the movement of other snails on or off a colony. These observations suggest that $C$. gibbosum produces and follows mucous trails as it moves between gorgonians. A number of other marine gastropods exhibit similar behavior (Paine 1963, Peters 1964, Crisp 1969, Cook 1971).

The number of Cyphoma gibbosum encountering a gorgonian is therefore influenced by mucous trails

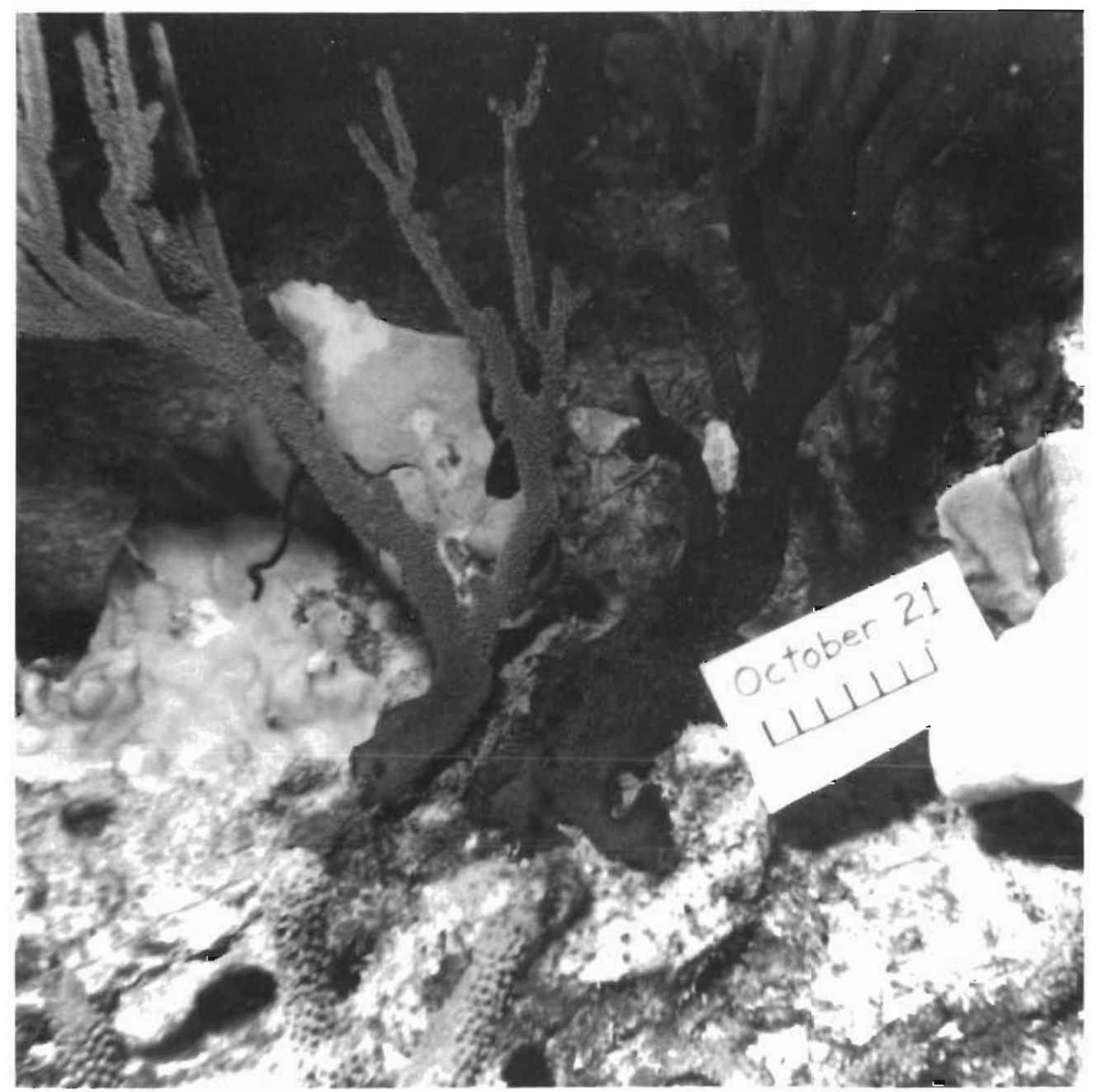

Fig. 3. Row of evenly spaced, shallow bites made by an individual Cyphoma gibbosum as it first occupied a gorgonian. The row of bites extends from the base of the colony to the snail, which can be seen half-way up the colony. Scale is in cm 
leading to the colony, while the residence time of a snail is influenced by the amount of prior predation on the colony. These 2 processes can explain several behavioral patterns of $C$. gibbosum. Assuming that the mucous trails are directionless, recently occupied colonies would tend to be occupied by additional $C$. gibbosum, while recently vacated colonies would tend to be colonized by a new snail. Thus, trail-following can account for the observations that some gorgonian colonies are chronically occupied by C. gibbosum, and that the snails are clumped into small groups (Hazlett $\&$ Bach 1982). Furthermore, snails that first colonize a gorgonian should remain for a relatively long time, since the colony has not been previously grazed. Additional snails will tend to follow the first colonizers, and the number of snails on the gorgonian will increase. As grazing continues, the acceptability of the colony will decrease, and snails should leave more and more quickly. Eventually, the rate of emigration should exceed the rate of colonization, and the number of snails on the gorgonian should decrease. Thus, the number of snails on a colony should increase, reach a plateau, and then begin to decline. Patterns of this type were observed in the field (Fig. 4).

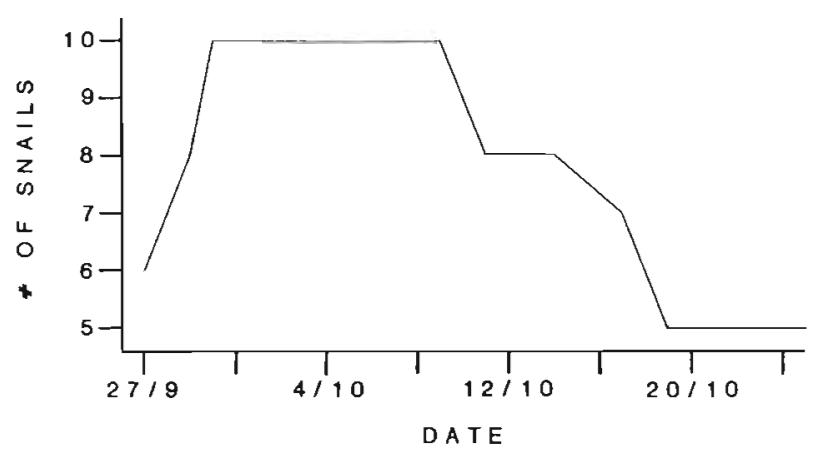

Fig. 4. Cyphoma gibbosum. Formation and dispersion of a group

Although trail-following provides a mechanism by which snails aggregate, it does not explain why Cyphoma gibbosum is gregarious. Grazing seems to decrease colony acceptability, yet snails seek out other snails. This suggests that gregariousness provides the snails with some benefit, which counter-balances the reduction in acceptability produced by grazing.

One possible explanation for the gregarious behavior is that Cyphoma gibbosum is distasteful, and that gregariousness leads to decreased predation by effectively conditioning predators to the unpalatability of the snails. The connection between gregarious behavior and distastefulness is well known in the terrestrial environment, and has been discussed for many years, usually in relation to kin selection (Fisher 1958).
Kin selection is unlikely in Cyphoma gibbosum, since this gastropod possesses a planktonic larval stage (Bandel 1973). The duration of the planktonic phase of C. gibbosum larvae is unknown. If the larvae of $C$. gibbosum remain in the plankton even for a very short length of time, however, then $C$. gibbosum would rarely occur in family groups.

Kin selection is not necessary, however, to explain gregariousness as a predation-reducing adaptation. Many coral reef predators have very restricted ranges (Cameron 1976). Gregariousness concentrates a number of snails in a small area; therefore, local predators should be familiar with the distasteful properties of the snails, and the mean number of attacks per snail should be low. If Cyphoma gibbosum were widely dispersed, each snail would be surrounded by naive predators, and the average number of attacks per snail would be high. Thus, gregariousness in C. gibbosum could lead to decreased susceptibility to predators.

The mantle of Cyphoma gibbosum does appear to be unpalatable, since bluehead wrasses tend to reject or ignore sections of this tissue. The behavior of $C$. gibbosum also suggests that the mantle provides protection by its distasteful qualities: when handled, $C$. gibbosum does not immediately retract its mantle, but keeps the mantle extended. At the same time, C. gibbosum curls its foot along the longitudinal axis, so that the sole is protected and only the outer surface is exposed. The outer part of the foot is covered with mantle tissue, and possesses a pattern of brown, zebrastyle stripes on an orange background. If handling continues, the mantle and foot are withdrawn.

Torn mantles were observed in some living Cyphoma gibbosum. These tears may have been inflicted during aborted attacks by predators. In danaine butterflies, beak marks, produced in attacks by birds, are found on the wings of distasteful butterflies more frequently than on those of palatable forms (Brower \& Glazier 1975). The presence of mantle tears on some $C$. gibbosum suggests that the distasteful mantle can provide a defense against predators.

The distastefulness of Cyphoma gibbosum may arise from the sequestering of gorgonian chemicals. C. gibbosum is known to contain gorgonian compounds in its tissues, although the presence of these compounds in the mantle of the gastropod has not yet been demonstrated (Steudler et al. 1977). Many gorgonian compounds are noxious or toxic, and seem to discourage predators (Tursch et al. 1978, Bakus 1981, Gerhart $1984 \mathrm{a})$. By sequestering these compounds, C. gibbosum may derive an effective defense from its prey. Other gastropods also sequester the secondary metabolites of their prey, apparently for defensive purposes (Faulkner \& Ghiselin 1983). 
The mantle of Cyphoma gibbosum is conspicuously colored (Bandel 1973, Hazlett \& Bach 1982). The distasteful qualities of the mantle suggest that these bright colors may serve an aposematic function.

Gregariousness in Cyphoma gibbosum also may be a mechanism to provide access to mates. Ghiselin \& Wilson (1966) stated that individuals of $C$. gibbosum frequently were found in pairs, and hypothesized that these pairs formed to allow copulation to take place. If so, then pairs of $C$. gibbosum should consist of 1 male and 1 female gastropod more frequently than expected by chance. At present, data on the sex ratios of $C$. gibbosum have not been gathered. Birkeland \& Gregory (1975) also noted that single individuals of $C$. gibbosum were observed less frequently than expected, and suggested that the drive to mate could cause $C$. gibbosum to aggregate into small groups. In Curaçao, I frequently observed copulating pairs of snails and the egg masses of $C$. gibbosum on snailoccupied gorgonians. Thus, the search for mates could explain the gregarious tendencies of $C$. gibbosum.

Although unpalatability and access to mates provide 2 explanations for gregariousness in Cyphoma gibbosum, other explanations cannot be ruled out. Trailfollowing could increase the chance of finding an acceptable colony, since a time period of several days or weeks may be required before a colony is rendered unacceptable. Mucous trail following also may allow C. gibbosum to find gorgonians more quickly, perhaps thus decreasing the energy expenditure of the gastropod, or reducing its exposure to predators. Other plausible hypotheses exist. Further research must be performed to determine the benefits of gregariousness in C. gibbosum.

Colonial marine invertebrates and their predators possess important parallels to terrestrial plant-herbivore interactions. In both systems, the capacity for regeneration in the prey, and the relatively slow rate of grazing of the predators, allows the predators to graze without usually killing their victims. In both systems, the prey are highly 'apparent' (Rhoades \& Cates 1976), long-lived relative to the predator, and protected by large concentrations of secondary compounds, as well as other defenses. Cyphoma gibbosum and other marine predators, especially opisthobranch and ovulid gastropods, appear frequently to parallel insect herbivores in their adaptations and behavior. The monarch butterfly Danaus plexippus is gregarious, distasteful, aposematically colored, and capable of sequestering noxious compounds from its prey (Brower \& Glazier 1975). The same suite of traits may have evolved in $C$. gibbosum. This may be more than a coincidence. The continued study of colonial marine invertebrates and their gastropod predators, and the comparison of them with terrestrial plant-herbivore interactions, may pro- duce new insight into the ecology and evolution of predator-prey interactions.

Acknowledgements. Charles Mangano provided superb support as a field and laboratory assistant. Oscar Franz, Frank Isabella, and Aubrey Teil assisted during many of the dives. The administration, staff, and researchers at CARMABI made my work there productive, stimulating, and enjoyable. Discussions with Dave Berg, Vince Cirillo, Ken Dunn, Douglas Futuyma, George Hechtel, Jeffrey Levinton, Rosemary Monahan, and Glenn Prestwich provided new perspectives and useful criticism. Robert Kinzie, Howard Lasker, Jeffrey Levinton, Paul Sammarco, and Paul Scheuer reviewed the manuscript and made many helpful suggestions. This research was supported by Sigma Xi, the Scientific Research Society; the Joseph Henry-O.C. Marsh Fund of the American Museum of Natural History; the Lerner Fund of the National Academy of Sciences; and a Pre-Doctoral Dissertation Improvement Grant from the National Science Foundation. I am grateful to all. This is contribution No. 581 from the Department of Ecology and Evolution, State University of New York at Stony Brook.

\section{LITERATURE CITED}

Bakus, G. J. (1964). The effects of fish-grazing on invertebrate evolution in shallow tropical waters. Occ. Pap. Allan Hancock Fdn 27: 1-29

Bakus, G. J. (1971). An ecological hypothesis for the evolution of toxicity in marine organisms. In: de Vries, A., Kochva, E. (ed.) Toxins of animal and plant origin. Gordon and Breach, New York, p. 57-61

Bakus, C. J. (1981). Chemical defense mechanisms on the Great Barrier Reef, Australia. Science 211: 497-499

Bandel, K. (1973). Notes on Cypraea cinerea (Gmelin) and Cyphoma gibbosum (Linnaeus) from the Caribbean sea and description of their spawn. Veliger 15: 335-337

Barnes, R. D. (1980). Invertebrate zoology, 4 th edn. Saunders College/Holt, Rinehart \& Winston, Philadelphia

Bayer, F. M. (1961). The shallow-water Octocorallia of the West Indian Region. (Studies on the Fauna of Curaçao and other Caribbean Islands, No.55.) Martinus Nijhoff, The Hague

Birkeland, C., Gregory, B. (1975). Foraging behavior and rates of feeding of the gastropod Cyphoma gibbosum. Sci. Bull. Mus. Nat. Hist. Los Angeles County 20: 57-67

Brock, R. E. (1979). An experimental study on the effects of grazing by parrotfishes and role of refuges in benthic community structure. Mar. Biol. 51: 381-388

Brower, L. P., Glazier, S. C. (1975). Localization of heart poisons in the monarch butterfly. Science 188: 19-25

Cameron, A. (1976). Toxicity of coral reef fishes. In: Jones, O. A., Endean, R. E. (ed.) Biology and geology of coral reefs, Vol. 3, Biology 2. Academic Press, New York, p. $155-176$

Cook, S. B. (1971). A study of homing behavior in the limpet Siphonaria alternata. Biol. Bull. mar biol. Lab., Woods Hole 141: 449-457

Crisp, M. (1969). Studies on the behavior of Nassarius obsoletus (Say) (Mollusca, Gastropoda). Biol. Bull. mar. biol. Lab., Woods Hole 136: 355-373

Dominguez, J. N., Adams, D. R., Flamerich, J. (1980). Isolation of prostaglandins from the gorgonian Plexaura homomalla collected off the Venezuelan coast. Rev. Latinoamer. Quim. 11: 56-58

Faulkner, D. J. (1984). Marine natural products: metabolites 
of marine invertebrates. Natural Products Reports 1: 551-598

Faulkner, D. J., Ghiselin, M. T (1983). Chemical defense and evolutionary ecology of dorid nudibranchs and some other opisthobranch gastropods. Mar Ecol. Prog. Ser. 13: 295-301

Fenical, W (1982). Natural products chemistry in the marine environment. Science 215: 923-928

Fisher, R. A. (1958). The genetical theory of natural selection. 2nd edn. Dover Press, New York

Gerhart, D. J. (1984a). Prostaglandin $\mathrm{A}_{2}$ : an agent of chemical defense in the Caribbean gorgonian Plexaura homomalla. Mar. Ecol. Prog. Ser. 19: 181-187

Gerhart, D. J. (1984b). The ecological roles of prostaglandin $\mathrm{A}_{2}$ in the Caribbean gorgonian Plexaura homomalla. Ph. D. diss., State Univ. of New York, Stony Brook

Ghiselin, M. T., Wilson, B. R. (1966). On the anatomy, natural history, and reproduction of Cyphoma, a marine prosobranch gastropod. Bull. mar. Sci. 16: 132-141

Glynn, P. W., Stewart, R. H., McCosker, J. E. (1972). Pacific coral reefs of Panama: structure, distribution, and predators. Sonderdruck aus der Geologischen Rundschau 61: 483-519

Hall, A. K., Behrman, H. R. (1982). Prostaglandins: biosynthesis, metabolism, and mechanism of cellular action. In: Lee, J. B. (ed.) Prostaglandins. Elsevier, New York, p. 1-38

Hazlett, B. A., Bach, C. E. (1982). Distribution pattern of the flamingo tongue shell (Cyphoma gibbosum) on its gorgonian prey (Briareum asbestinum). Mar. Behav. Physiol. 8: 305-309

Huston, M. A. (1985). Patterns of species diversity on coral reefs. Ann. Rev. Ecol. Syst. 16: 149-177

Hyman, L. H. (1940). The invertebrates: Protozoa through Ctenophora. McGraw-Hill, New York

Kinzie, R. A. (1971). The ecology of the gorgonians (Cnidaria, Octocorallia) of Discovery Bay, Jamaica. Ph. D. diss., Yale University

Nakano, J. (1968). Effect of prostaglandins $E_{1}, A_{1}$, and $F_{2 \pi}$ on cardiovascular dynamics in dogs. In: Ramwell, P. W. Shaw, J. E. (ed.) Prostaglandin symposium of the Worcester Foundation for experimental biology. John Wiley and Sons, New York, p. 201-214

Nakano, J. (1969). Cardiovascular effect of a prostaglandin isolated from a gorgonian Plexaura homomalla. J. Pharm. Pharmacol. 21: 782-783

Nakano, J., Kessinger, J. M. (1970). Effect of 15(R)-PGA $A_{2}$ on the cardiovascular responses to $\mathrm{PGA}_{2}$ in dogs. Clin. Res. 18: 117

Paine, R. T (1963). Food recognition and predation on opisthobranchs by Navanax inermis. Veliger 6: $1-9$

Paine, R. T (1966). Food web complexity and species diversity. Am. Nat. 100: 65-76
Peters, R. L. (1964). The function of the cephalic tentacles in Littorina. Veliger $7 \cdot 143-148$

Randall, J. E. (1967). Food habits of reef fishes of the West Indies. Stud. Trop. Oceanogr. 5: 665-847

Rhoades, D. F., Cates, R. G. (1976). Toward a general theory of plant anti-herbivore chemistry. In: Wallace, J., Mansell, $R$. (ed.) Biochemical interactions between plants and insects. Rec. Adv. Phytochem. 40: 168-213

Sammarco, P. W. (1980). Diadema and its relationship to coral spat mortality: grazing, competition, and biological disturbance. J. exp. mar. Biol. Ecol. 45: 245-272

Sammarco, P. W., Levinton, J. S., Ogden, J. C. (1974). Grazing and control of coral reef community structure by Diadema antillarum Phillippi (Echinodermata: Echinoidea): a preliminary study. J. mar. Res. 32: 47-53

Schneider, W. P., Bundy, G. L., Lincoln, F. H., Daniels, E. G., Pike, J. E. (1977). Isolation and chemical conversions of prostaglandins from Plexaura homomalla: preparation of prostaglandin $E_{2}$, prostaglandin $F_{2 d}$, and their 5,6-trans isomers. J. Am. chem. Soc. 99: 1222-1232

Schneider, W. P., Morge, R. A. (1971). Search for prostaglandins in marine specimens from American and African waters. Upjohn Technical Report 3102/71/7231/002. Upjohn Co., Kalamazoo, Michigan

Slobodkin, L. B. (1962). Growth and regulation of animal populations. Holt, Rinehart, and Winston, New York

Sokal, R. R., Rohlf, F. J. (1981). Biometry: principles and practice of statistics in biological research. 2nd edn. Freeman, San Francisco

Spraggins, R. L. (1972). $\mathrm{PGA}_{2}$ and isomers from coral prostaglandins. Tetrahedron Lett. 42: 4343-4346

Steudler, P. A., Schmitz, F. J., Ciereszko, L. S. (1977). Chemistry of coelenterates. Sterol composition of some predatorprey pairs on coral reefs. Comp. Biochem. Physiol. 56B: 385-392

Tursch, B., Braekman, J. C., Daloze, D., Kaisin, M. (1978). Terpenoids from coelenterates. In: Scheuer, P. J. (ed.) Marine natural products, Vol. II. Academic Press, New York, p. 247-296

Van den Hoek, C., Breeman, A. M., Bak, R. P. M., Van Buurt, G. (1978). The distribution of algae, corals and gorgonians in relation to depth, light attenuation, water movement and grazing pressure in the fringing coral reef of Curaçao, Netherlands Antilles. Aquat. Bot. 5: 1-46

Vermeij, G. J. (1978). Biogeography and adaptation: patterns of marine life. Harvard University Press, Cambridge

Weinheimer, A. J., Spraggins, R. L. (1969). The occurrence of two new prostaglandin derivatives (15-epi-PGA $A_{2}$ and its acetate, methyl ester) in the gorgonian Plexaura homomalla. Chemistry of coelenterates XV. Tetrahedron Lett. 59: 5185-5188

This article was submitted to the editor; it was accepted for printing on March 12, 1986 